\title{
Study of Glucosamine Production from Shrimp Shells by Fermentation Using Trichoderma harzianum
}

\author{
Hardoko*, Bambang B. Sasmito, Yunita E. Puspitasari, Hamid M. Afandi, \\ Nugroho Maulia
}

Faculty of Fisheris and Marine Sciences, University of Brawijaya, Malang, Indonesia

\begin{abstract}
Shrimp shells are one of chitin sources in Indonesia which is potential to be converted into multifunctional glucosamine. This research was aimed to study the glucosamine production by fermentation using Trichoderma harzianum. Method used was experimental fermentation with $\mathrm{pH}$ treatment of 3-5 and fermentation duration of 10-20 days, and designed using Response Surface Methodology (RSM). Results showed that fermentation duration of 10-20 days has reached the optimum point of glucosamine production from shrimp shells using $T$. harzianum. The highest production of $D$ glucosamine in fermentation using T. harzianum occurred on initial $\mathrm{pH}$ of 5.41 and fermentation duration of 15 days $(18,294.95 \mathrm{ppm})$, while the highest N-Acethyl-D-Glucosamine production occurred on initial pH of 3.00 and fermentation duration of 20 days (127,000.00 ppm).
\end{abstract}

Keywords: fermentation, glucosamine, shrimp shells, T. harzianum.

\section{INTRODUCTION*}

Shrimp is one of the important export commodities for fishing industry in Indonesia. Majority of shrimp export from Indonesia is done in form of frozen unshelled shrimp, therefore shrimp shell is considered as waste or unused byproducts. The shrimp waste produced is around $30-35 \%$ of total weight of a shrimp [1]. Shrimp waste, such as shells can cause environmental problem if they are left unutilized.

Meanwhile, shrimp shells contain $25-40 \%$ of protein, $45-50 \%$ of calcium carbonate and 15$20 \%$ of chitin, depend on the types of shrimp [2]. Thus, shrimp shells can be used as a source of protein, calcium and chitin. Among those three components, the most potential component, in terms of economic value, is chitin. This is because chitin and its derivatives are very useful to be used in many industrial fields [3].

Chitin and its derivatives are commonly used in several fields, such as medical and health, i.e. they can be used as immunoadjuvant (nonspecific stimulator of immune response) and basic material to make surgical suture [4]. Nacetyl glucosamine compound, the product of chitin hydrolysis, is used in treatment of osteoarthritis and used as supplement [5,6]. In aesthetic field, chitin derivatives can be used as basic ingredients for cosmetics, toothpaste, body cream and hair treatment products. In textile,

\footnotetext{
* Correspondence address:

Hardoko

Email : hardoko@ub.ac.id

Address : Faculty of Fisheries and Marine Sciences, University of Brawijaya, Jl. Veteran , Malang 65145
}

they are widely used as coating material for cellulose fiber, nylon, cotton and wool [4].

Glucosamine is one of chitin derivatives that are widely used. Glucosamine production can be done physicochemically [7-11], enzymatically [1215] and microbiologically [16]. To produce glucosamine chemically is relatively fast, but the chemical compounds used are dangerous for the environment, meanwhile to produce glucosamine enzymatically, the limitations are on the stability of enzyme and enzyme extraction cost that are quite expensive $[17,18]$. To produce monomer (likes glukosa, glucosamine) using microorganism is more advantageous because it is easier, more practical and the waste does not pollute the environment [19].

Glucosamine production using microorganisms is usually done by fermentation. There are many kinds of microorganisms, including bacteria and molds that can produce chitinolytic enzyme that can break down chitin into glucosamine. One of the microorganisms that can produce chitinase quite actively is Trichoderma. One of the strains, $T$. viride, produces chitinase enzyme with enzyme activity value of about $210.14{\text { U. } \mathrm{mg}^{-1}}^{-1}[20]$.

Trichoderma have several strains and in this research, the characteristics of Trichoderma harzianum in fermenting chitin into glucosamine with different $\mathrm{pH}$ condition and fermentation duration using RSM method, was studied.

\section{MATERIALS AND METHODS}

Method used in chitin fermentation was experimental method with design and analysis using Response Surface Methodology. Treatment 
or random variables applied in this fermentation experiment were $\mathrm{pH}\left(\mathrm{X}_{1}=3,4,5\right)$ and fermentation duration $\left(X_{2}=10,15,20\right.$ days). The determination of fermentation duration was based on report [21,22] that optimum fermentation duration of Trichoderma was 15 days, whereas the $\mathrm{pH}$ of fermentation was based on optimum $\mathrm{pH}$ for $T$. harzianum growth [23], i.e. $\mathrm{pH}$ of 5.6. The experimental matrix was derived by Software Design Expert, as can be observed on Table 1. The fixed factor was nutrition composition inside the fermentation media $\left(\mathrm{KH}_{2} \mathrm{PO}_{4}\right.$ and $\left.\mathrm{MgSO}_{4}\right)$ and fermentation temperature, i.e. about $30^{\circ} \mathrm{C}$ (room temperature). Therefore, the treatment applied in this research was combination from initial $\mathrm{pH}$ column and duration column, i.e. 21 treatments (run column).

\begin{tabular}{|c|c|c|c|c|}
\hline Std & Run & Block & $\begin{array}{c}\text { Initial } \\
\text { pH }\end{array}$ & $\begin{array}{c}\text { Duration } \\
\text { (days) }\end{array}$ \\
\hline 11 & 1 & Block 1 & 5.41 & 15.00 \\
\hline 21 & 2 & Block 1 & 4.00 & 15.00 \\
\hline 12 & 3 & Block 1 & 5.41 & 15.00 \\
\hline 3 & 4 & Block 1 & 5.00 & 10.00 \\
\hline 16 & 5 & Block 1 & 4.00 & 22.07 \\
\hline 2 & 6 & Block 1 & 3.00 & 10.00 \\
\hline 15 & 7 & Block 1 & 4.00 & 22.07 \\
\hline 4 & 8 & Block 1 & 5.00 & 10.00 \\
\hline 5 & 9 & Block 1 & 3.00 & 20.00 \\
\hline 20 & 10 & Block 1 & 4.00 & 15.00 \\
\hline 17 & 11 & Block 1 & 4.00 & 15.00 \\
\hline 14 & 12 & Block 1 & 4.00 & 7.93 \\
\hline 19 & 13 & Block 1 & 4.00 & 15.00 \\
\hline 9 & 14 & Block 1 & 2.59 & 15.00 \\
\hline 13 & 15 & Block 1 & 4.00 & 7.93 \\
\hline 6 & 16 & Block 1 & 3.00 & 20.00 \\
\hline 10 & 17 & Block 1 & 2.59 & 15.00 \\
\hline 8 & 18 & Block 1 & 5.00 & 20.00 \\
\hline 18 & 19 & Block 1 & 4.00 & 15.00 \\
\hline 7 & 20 & Block 1 & 5.00 & 20.00 \\
\hline 1 & 21 & Block 1 & 3.00 & 10.00 \\
\hline
\end{tabular}

Note: Std $=$ Standard

\section{Preparation of Chitin from Shrimp Shells}

Chitin isolation from Vannamei shrimp shells was performed by demineralization step using $\mathrm{HCl}$ and deproteination using $\mathrm{NaOH}$ [24]. First, Vannamei shrimp shells were washed and dried under sunlight until dry and then milled using Buhrmill and sieved using 60 mesh sieve to obtain shrimp shells powder.

Shrimp shells powder was then added with $1.5 \mathrm{M} \mathrm{HCl}$ with ratio of $1: 15(\mathrm{w} / \mathrm{v})$ between sample and solvent. The mixture was then heated at temperature of $70-80^{\circ} \mathrm{C}$ for 4 hours under agitation of $50 \mathrm{rpm}$, and was filtered afterwards. The solid obtained was washed with aquadest to remove the remaining $\mathrm{HCl}$. Then, the solid was dried in the oven with temperature of $70^{\circ} \mathrm{C}$ for 24 hours and cooled inside the desiccator, to obtain low mineral shrimp shells powder.

Demineralized shrimp shells powder was put into beaker glass and added with $3.5 \% \mathrm{NaOH}$ solution with ratio of $1: 10(\mathrm{w} / \mathrm{v})$. The mixture was then heated at temperature of $65-70^{\circ} \mathrm{C}$ for 4 hours under agitation of $50 \mathrm{rpm}$. The mixture was filtered to obtain chitin solids and washed with aquadest until neutral $\mathrm{pH}$ is obtained.

\section{Fermentation of Chitin from Shrimp Shells using T. harzianum}

Fermentation of chitin using $T$. harzianum was performed using semi solid fermentation system. The substrate consists of 5 gram of chitin, 0.05 gram of $\mathrm{KH}_{2} \mathrm{PO}_{4}, 0.25$ gram of $\mathrm{MgSO}_{4}$, 0.05 gram of urea, 1 gram of glucose, and $25 \mathrm{ml}$ of aquadest [25].

The substrate was then sterilized using autoclave with temperature of $121^{\circ} \mathrm{C}$ for 15 minutes. When the substrate has cooled down, $\mathrm{pH}$ was set according to the treatment using 0.1 $\mathrm{M} \mathrm{NaOH}$ and/or $0.1 \mathrm{M} \mathrm{HCl}$. Each substrate was added with $1 \mathrm{~mL}$ of $T$. harzianum spore and fermented at room temperature using shaker fermenter.

\section{Chitinolytic Activity Test by Clear Zone Measure- ment}

Chitinolytic activity test was done by observing the clear zone formed on agar media enriched with chitin, surrounding the growth of molds. Agar-chitin media was made from PDA added with $0.5 \%$ colloidal chitin ( $w / v$ media) [26, 27] and acidified using $50 \%$ lactic acid for about $0.14 \%$ from total volume of media [28]. This media was then sterilized using autoclave with temperature of $121^{\circ} \mathrm{C}$, pressure of 1 atm for 15 minutes. The media was then poured into Petri dish and let solidify. After the media has solidified, a well with $6 \mathrm{~mm}$ diameter was made, aseptically. Then, $20 \mu \mathrm{L}$ of $T$. harzianum spores with density of $20.48 \times 10^{7} \cdot \mathrm{mL}^{-1}, 38.48 \times 10^{7} \cdot \mathrm{mL}^{-1}$, $63.52 \times 10^{7} \cdot \mathrm{mL}^{-1}, 158.72 \times 10^{7} \cdot \mathrm{mL}^{-1}$, were respectively added into the well ( $6.0 \mathrm{~mm}$ diameter), and incubated at temperature of $35^{\circ} \mathrm{C}$ for 48 hours. Chitinolytic activity was determined by measuring the clear zone formed, i.e. by subtracting diameter of clear zone formed from diameter of well. 


\section{Glucosamine Analysis using Spectrophotometry Method [29]}

About 0.01 gram of fermented sample was dissolved uisng $1 \mathrm{~mL}$ of $0.25 \mathrm{M} \mathrm{CH}_{3} \mathrm{COONa}$ to obtain concentration of $10,000 \mathrm{mg} \cdot \mathrm{L}^{-1}$. This solution was then diluted gradually until concentration of $12 \mathrm{ppm}$ and 100 ppm were obtained. Each sample (concentration of $12 \mathrm{ppm}$ and $100 \mathrm{ppm}$ ) was reacted with same concentration of PITC. The absorbance of sample solution of $12 \mathrm{ppm}$ concentration that has been added with PITC was determined using UV-Vis spectrophotometer at wavelength of $273 \mathrm{~nm}$ to obtain absorbance of DGlucosamine compound. Meanwhile, the absorbance of sample solution of $100 \mathrm{ppm}$ concentration that has been added with PITC was determined using UV-Vis spectrophotometer at wavelength of $584 \mathrm{~nm}$ to obtain absorbance of $\mathrm{N}$-Acethyl-D-Glucosamine compound. These absorbance results were then plotted on standard curve of D-Glucosamine and N-AcethylD-Glucosamine.

Standard curve of D-Glucosamine and $\mathrm{N}$ Acethyl-D-Glucosamine were prepared by dissolving 0.01 gram of standard D-Glucosamine or N-Acethyl-D-Glucosamine in $10 \mathrm{~mL}$ of $0.25 \mathrm{M}$ $\mathrm{CH}_{3} \mathrm{COONa}$ and allowed to stand for 24 hours (to stabilize the solution). After that, standard DGlucosamine or N-Acethyl-D-Glucosamine solution with concentration of $1,000 \mathrm{ppm}$ as a stock solution was obtained. The stock solution was then diluted to obtain concentration of $3,6,9$ and $12 \mathrm{ppm}$. About $10 \mathrm{~mL}$ of each solution was added with $10 \mathrm{~mL}$ of PITC solution, homogenized for 5 minutes and derivatives compound, i.e. phenylthiourea (PTH), was obtained. The absorbance of this compound can be determined according to the wavelength used. In this case, PITC solution was prepared by dissolving PITC using methanol that has the same concentration with glucosamine standard solution.

\section{RESULT AND DISCUSSION \\ Characteristics of Chitin from Shrimp Shells}

Table 2 shows that chitin used has not fulfilled the commercial chitin standard in terms of protein content, although its moisture content, mineral content and deacetylation degree have fulfilled the commercial chitin standard. High protein content in chitin indicates that deproteination process was not enough. This might be caused by insufficient $\mathrm{NaOH}$ concentration and/or insufficient deproteination process. Effectivity of deproteination process depends on the concentration of basic solution and tempera- ture used [30]. Besides, protein content of chitin is related to its moisture content [30]. Lots of protein matrix that have been degraded cause hydrophilic properties of protein to bind water molecule becomes weaker[33]. As a result, the moisture content will become less [31]. It is shown by the moisture content of shrimp shells which is about $60-65 \%$ [32].

\begin{tabular}{lccc}
\multicolumn{4}{c}{ Table 2. Characteristics of Chitin and Dried Shrimp Shells } \\
\hline $\begin{array}{c}\text { Parameter } \\
\text { (\%) }\end{array}$ & $\begin{array}{c}\text { Dried } \\
\text { Shrimp } \\
\text { Shells }\end{array}$ & Chitin & $\begin{array}{c}\text { Commer- } \\
\text { cial } \\
\text { Chitin }\end{array}$ \\
\hline Moisture & $10.07 \pm 0.26$ & $6.69 \pm 0.21$ & $<10^{*}$ \\
Protein & $42.41 \pm 4.21$ & $13.2 \pm 1.42$ & $<1^{*}$ \\
Mineral & $19.75 \pm 0.39$ & $1.42 \pm 0.09$ & $<2.5^{*}$ \\
$\begin{array}{l}\text { Deacetyla- } \\
\text { tion degree }\end{array}$ & - & 35.16 & $15-70^{* *}$ \\
\hline $\begin{array}{l}\text { Note : }{ }^{*} \text { Commercial food grade chitin[33]; } \\
* *\end{array}$ &
\end{tabular}

\section{Chitinolytic Activity of $T$. harzianum Molds}

Chitinolytic activity of molds is defined as the ability of molds to degrade chitin into other simpler compounds, e.g. glucosamine by chitinase enzyme. This activity can be measured by clear zone formation around the wells, paper disc or colony $[20,35,36]$. In this research, chitinolytic activity obtained based on clear zone formation was used to determine the amount of spores added during chitin fermentation. The results of clear zone based on density of $T$. harzianum spores can be observed on Table 3.

Table 3. Clear zone formation based on density of Trichoderma harzianum spores

\begin{tabular}{lc}
\hline Density (spore. $\mathrm{mL}^{-1}$ ) & Clear zone $(\mathrm{mm})^{*}$ \\
\hline $20.48 \times 10^{7}$ & $6.52 \pm 0.73$ \\
$38.48 \times 10^{7}$ & $5.93 \pm 0.91$ \\
$63.52 \times 10^{7}$ & $4.67 \pm 1.28$ \\
$158.72 \times 10^{7}$ & $2.95 \pm 0.17$ \\
\hline
\end{tabular}

*Note: clear zone $=$ diameter of clear zone - diameter of well

The size of clear zone formed shows the amount of $\mathrm{N}$-acetylglucosamine formed from chitin breakdown by chitinase enzyme. The larger the clear zone, the higher amount of chitinase formed, which means the higher the chitinolytic activity [36]. Based on Table 3, it can be observed that the largest clear zone diameter for $T$. harzianum molds was obtained from spores with density of $20.48 \times 10^{7}$ spores. $\mathrm{mL}^{-1}$, with clear zone of $6.52 \pm 0.73 \mathrm{~mm}$, and then decreased as the spore density was increased. The smallest clear zone occurred at density of $63.52 \times 10^{7}$ spores. $\mathrm{mL}^{-1}$ with clear zone of $2.95 \pm 0.17 \mathrm{~mm}$. This might happen because the spore density of $20.48 \times 10^{7}$ spores. $\mathrm{mL}^{-1}$ was the most effective; 
therefore there was no growth competition among the molds. Thus, $T$. harzianum can work optimally to degrade chitin during fermentation. Chitin degradation is done by chitinase enzyme that has different activity based on the types and stage of growth of microorganisms, and factors which influence the growth of microorganisms, such as $\mathrm{pH}$, temperature and fermentation period $[12,37,38]$. Chitinase activity from Trichoderma sp. and T. viridae was $33.19 \mathrm{IU} . \mathrm{mL}^{-1}$ and 18.77 IU. $\mathrm{mL}^{-1}$, respectively [20].

\section{Glucosamine Production}

Glucosamine that is obtained from chitin fermentation can be in form of D-glucosamine and N-Acethyl-D-Glucosamine. The correlation between $\mathrm{pH}$ and fermentation duration of shrimp shells chitin for glucosamine production according to RSM program can be observed on Figure 1.

\section{A) D-Glucosamine}

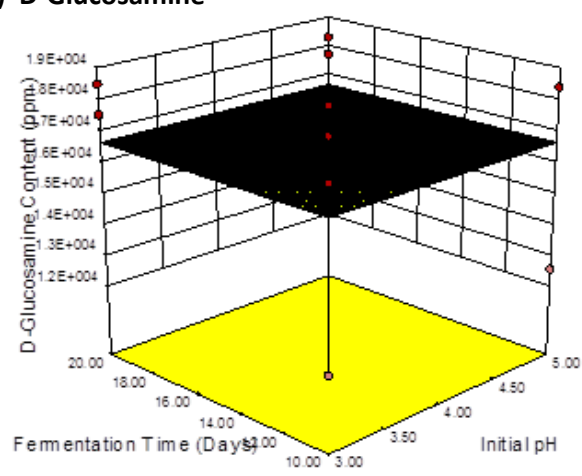

B) N-Acethyl-D-Glucosamine

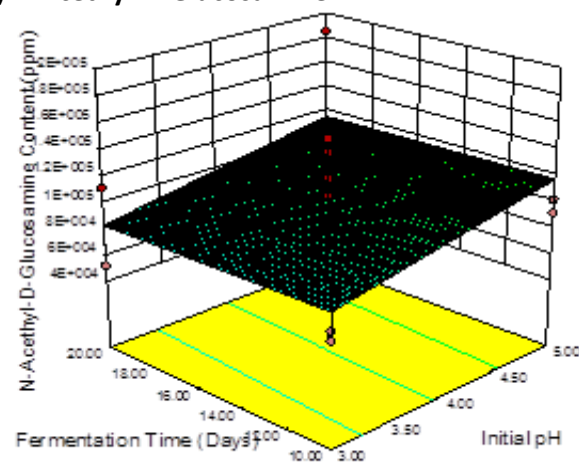

Figure 1. Three-dimensional RSM graph of correlation between $\mathrm{pH}$ and fermentation duration of shrimp shells chitin for glucosamine production using $T$. harzianum

Three-dimensional RSM graph on Figure 1 shows the flat shape of correlation between $\mathrm{pH}$ and fermentation duration of shrimp shells chitin for glucosamine production, which means there was no optimum point. This phenomenon shows there was no significant effect of fermentation duration and $\mathrm{pH}$ on D-Glucosamine and $\mathrm{N}$-acetylD-Glucosamine obtained. This might happen because the fermentation duration was too long; therefore the production of D-Glucosamine is already maximum since the first observation (day 10) and there was only slight difference in glucosamine content on the following observations. It is based on a previous research that stated the production of chitinase by fermentation using $T$. harzianum reached its highest amount after 72 hours (day 3) when $T$. harzianum mycelia starter was used and after 96 hours (day 4) when $T$. harzianum spore starter was used [39].

This statement is also supported by another research that stated chitinolytic activity of $T$. harzianum reached its optimum amount in between day 2 and day 3 [40]. No significant change of glucosamine production after it has reached its optimum point is also in accordance with a research [41] which stated after 172 hours, glucosamine fermentation using $T$. harzianum mold starter did not undergo significant increase. Because there was no optimum point for glucosamine production, the glucosamine production can be observed based on interaction between $\mathrm{pH}$ and fermentation duration, as can be seen on Figure 2 .

Figure 2 shows that the highest $D$ glucosamine amount obtained from $\mathrm{pH}$ treatment of 5.41 and fermentation duration of 15 days, which produces $D$-glucosamine content of $18,294.95 \mathrm{ppm}$. This amount of glucosamine is still higher compared to other research reports. Fermentation using chitinase from Pseudomonas sp. was optimum after 35 hours, which produces $0.164 \mathrm{mg} \cdot \mathrm{mL}^{-1} 164 \mathrm{ppm}$ of glucosamine [14], using Actinomycetes ANL-4 starter produces highest glucosamine about 9,784.25 ppm on day 5 [29], using Aspergillus sp. BCRC 31742 produces highest glucosamine of 7,480 ppm [42].

The highest $\mathrm{N}$-acetyl-D-Glucosamine production in fermentation of shrimp shells chitin using T. harzianum obtained from $\mathrm{pH}$ treatment of 5 and 10 days of fermentation, which produces $\mathrm{N}$ acetyl-D-Glucosamine of $127,000.00 \mathrm{ppm}$. This amount of glucosamine is still higher compared to other research reports. Fermenta-tion using Aspergillus rogulosus 501 on day 10 obtained Nacetyl-D-Glucosamine of 2,228 ppm [43], fermentation using enzyme combination from $T$. harzianum and $T$. reesei was highest after 72 and 96 hours of incubation, which was about 4,040 ppm [39], fermentation using T. harzianum was 
highest after 212 hours, which was about 190 ppm [40].

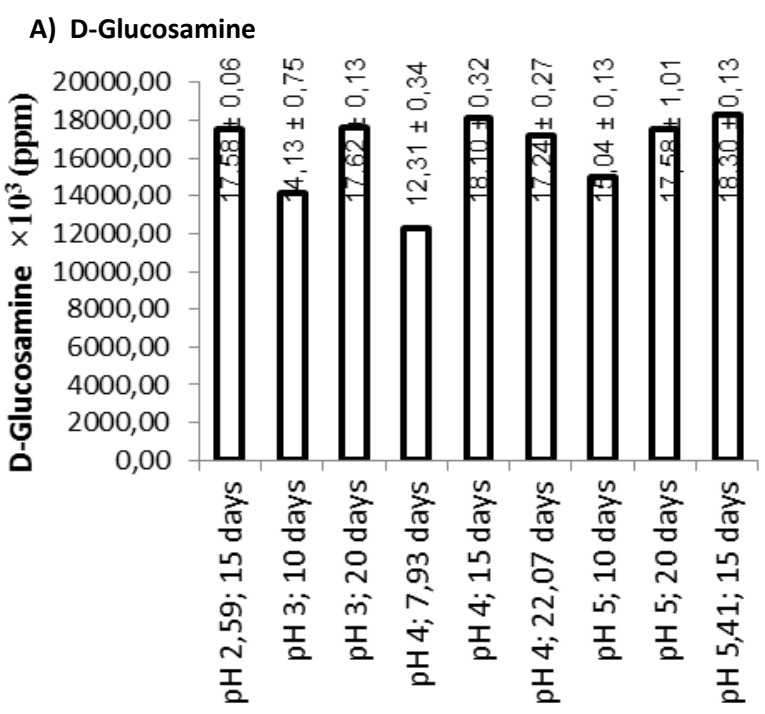

\section{Interaction}

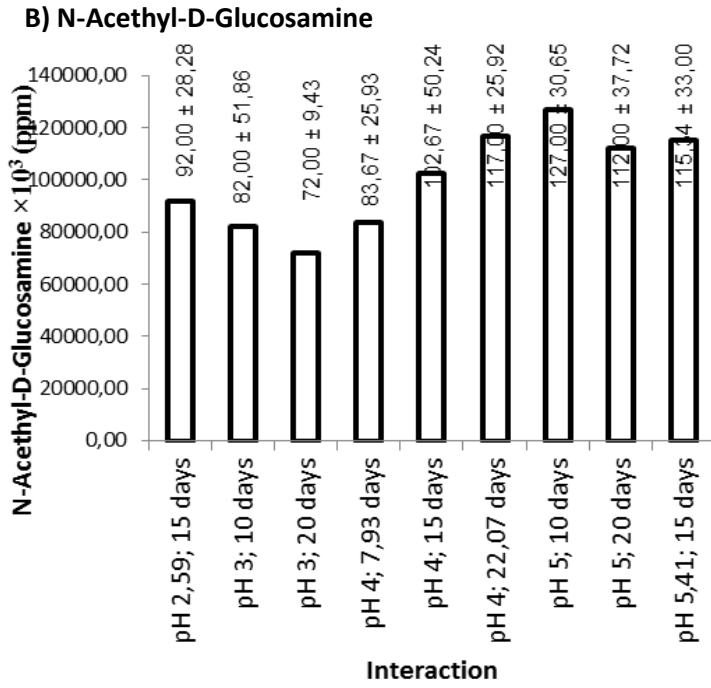

Figure 2. Graph of interaction between fermentation factors and their influence on glucosamine content

\section{CONCLUSION}

The fermentation duration applied on optimization of fermentation of shrimp shells chitin for glucosamine production using $T$. harzianum was too long. The highest production of D-Glucosamine from fermentation using $T$. harzianum occurred on initial $\mathrm{pH}$ of 5.41 and fermentation duration of 15 days, which reached about 18,294.95 ppm, whereas the highest production of N-Acethyl-D-Glucosamine occurred on initial $\mathrm{pH}$ of 3.00 and fermentation duration of 20 days, which reached about $127,000.00$ ppm.

\section{ACKNOWLEDGEMENT}

The authors would like to thank Ministry of Research, Technology and Higher Education who has granted the research fund through INSINAS program, FY 2016.

\section{REFERENCES}

[1] Darmawan, E., S. Mulyaningsih, F. Firdaus. 2007. Karakteristik khitosan yang dihasilkan dari limbah kulit udang dan daya hambatnya terhadap pertumbuhan Candida albicans. Logika. 4. 207-213.

[2] Foucher, J.P., G.K. Westbrook, A. Boetius, S. Ceramicola, S. Dupre, J. Mascle, J. Mienert, O. Pfannkuche, C. Pierre, D. Praeg. 2009. Structure and drivers of cold seep ecosystems. Oceanography. 22. 92109.

[3] Hargono, Abdullah, I. Sumantri. 2008. Pembuatan kitosan dari limbah cangkang udang serta aplikasinya dalam mereduksi kolesterol lemak kambing. Reaktor. 12(1). 53-57.

[4] Kaban, J. 2009. Modifikasi kimia dari kitosan dan aplikasi produk yang dihasilkan. Master Thesis. Department of Chemistry. University of North Sumatera. Medan.

[5] Sashiwa , H., S. Fujishima, N. Yamano, N. Kawasaki, A. Nakayama, E. Muraki, K. Hiraga, K. Oda, S. Aiba. 2002. Production of N-Acetyl-D-Glucosamine from chitin by crude enzymes from Aeromonas hydrophila H-2330. Carbohyd.Res. 337. 761-763.

[6] Kardiman, C. 2013. Manfaat glukosamin, kondroitin, dan metilsulfonilmetana pada osteoartritis. CDK-211. 40 (12). 936-939.

[7] Suptijah, P., B. Ibrahim, Ernawati. 2014. Pemanfaatan limbah krustasea dalam pembuatan glukosamin hidroklorida dengan metose autoklaf. Jurnal Teknologi Perikanan dan Kelautan. 5(2). 173-181.

[8] Dewi, N.L., S. Bahri, H. Jaya. 2016. Penggunaan berbagai tekanan dan waktu hidrolisis pada produksi glukosamin hidroklorida dari kitosan cangkang Bekicot (Achatina fulica). Kovalen. 2(1). 22-32.

[9] Nurjannah, A., Darmanto, I. Wijayanti. 2016. Optimasi pembuatan glukosamin hidroklorida (GLCN $\mathrm{HCl}$ ) dari limbah cangkang udang rajungan melalui hidrolisis kimiawi. JPHPI. 19(1). 26-35.

[10] Mukti, M.I., N. Herdyastuti. 2016. Karakterisasi $\mathrm{N}$-asetilglukosamin hasil hidrolisis kitin secara kimiawi. Proceeding of 
National Seminar on Chemistry and Its Learning. 61-64.

[11] Zaeni, M., E. Safitri, I.N. Sudiana. 2017. Pembuatan glukosamin hidroklorida dari cangkang udang dengan energi microwave Jurnal Aplikasi Fisika. 13(1). 22-26.

[12] Widhyastuti, N. 2007. Produksi kitinase ekstraseluler Aspergillus rugulosus 501 secara optimal pada media cair. Berita Biologi. 8(6). 547-553.

[13] Widhyastuti, N., M Ilyas. 2012. Aktivitas dan karakter kitinase isolat Trichoderma sp. W34 A4 asal Kepulauan Raja Ampat Papua Barat. Biosfera. 29(1). 1-7.

[14] Wirawan, A., N. Herdyastuti. 2013. Penentuan waktu inklubasi pada pembentukan senyawa $\mathrm{N}$-asetilglukosamin yang didegradasi secara enzimatis dari kitin. J. Chem. 2(3): 11-13.

[15] Purnomo, E.H., A.B. Sitanggang, D. Indrasti. 2012. Studi kinetika produksi glukosamin dalam Watermiscible Solvent dan proses separasinya. Proceeding of Seminar on Research Results. Bogor Agricultural University. Bogor. 24-25.

[16] Sharaf, E.F., A.E.Q. El-Sarrany, M. El-Deeb. 2012. Biorecycling of shrimp shell by Trichoderma viride for production of antifungal chitinase. Af. J. Microbiol. Res. 6 (21). 4538-4545.

[17] Palonen, H. 2004. Role of lignin in the enzymatic hydrolysis of lignocellulose. VTT Biotechnology. Helsinki University of Technology, Espoo, Finland.

[18] Taherzadeh, M.J., K. Karimi. 2008. Pretreatment of lignocellulosic waste to improve bioethanol and biogas production. Int. J. Mol. Sci. 9. 1621-1651.

[19] Suhartati, F.M., W. Suryapratama, N. Iriyanti. 2003. Sintesis asam amino metionin pada Trichoderma reseii dan pengaruhnya terhadap sintesisis protein mikroba rumen. Jurnal Peternakan dan Lingkungan. 9. 12-16.

[20] Khikmah, N., S. Margino, R.S. Kasiamdari. 2016. Isolasi, seleksi, dan identifikasi kapang kitinolitik yang diisolasi dari tanah pembuangan limbah udang dan Rizosfer Solanaceae. Biota. 1(1). 1-8.

[21] Saparianti, E., T. Dewanti, S.K Dhoni. 2012. Hidrolisis ampas tebu menjadi glukosa cair oleh kapang Trichoderma viride. Jurnal Teknologi Pertanian. 5(1). 1-10.

[22] Montesqrit. 2007. Isolasi dan karakterisasi selulase dari Trichoderma viride dan
Rhizopus spp dengan substrat jerami padi. Jurnal Peternakan Indonesia. 12(2).112123.

[23] Kapat, A., S.K. Rakshit, T. Panda. 1996. Optimization of carbon and nitrogen sources in the medium and environmental factors for enhanced production of chitinase by Trichoderma harzianum. Bioprocess Eng. 15. 13-20.

[24] Puspawati, N.M., I.N. Simpen. 2010. Optimasi deasetilasi khitin dari kulit udang dan cangkang kepiting limbah restoran seafood menjadi khitosan melalui variasi konsentrasi $\mathrm{NaOH}$. Jurnal Kimia. 4(1). 79-90.

[25] Saskiawan, I., R. Handayani. 2011. Hidrolisis kitin melalui fermentasi semi padat untuk produksi N-Asetilgukosamin. Berita Biologi. 10(6). 121-127.

[26] Hsu, S.C., J.L. Lockwood. 1975. Powdered chitin agar as a selective medium for enumeration of Actinomycetes in water and soil. Appl. Microbiol. 29(3). 422-426.

[27] Cahyani, L. 2013. Pemanfaatan tepung cangkang udang sebagai media produksi kitinase oleh bakteri kitinolitik Isolat 26. Bachelor Thesis. Department of Biology, University of Jember. Jember.

[28] El-Gholl N.E., A.C. Alfenas, P.W. Crous, T.S. Schubert. 1993. Description and pathogenicity of Cylindrocladium ovatum s. nov. Can. J. Bot. 71. 466-470.

[29] Utami, P.H. 2014. Penetapan waktu inkubasi optimum degradasi kitin oleh kitinase dari Actinomycetes ANL-4 secara spektrofotometri UV-Vis. Bachelor Thesis. Department of Chemistry. University of Lampung. Lampung. 45-46.

[30] Karmas, E. 1982. Poultry and seafood technology. Noyes Data Corporation. USA.

[31] Knorr, D. 1991. Recovery and utilization of chitin and chitosan in food processing waste management. Food Technol. 45(1). 114-122.

[32] Cha, D.S., M.S. Chinnan. 2004. Biopolymerbased antimikrobial packaging: a review. Critical Rev. Food Sci. Nutr. 44. 223-237.

[33] Subasinghe, S. 1999. Chitin from shellfish waste health benefits over shadowing industrial uses. Infofish. Int. 3. 58-65.

[34] Bastaman, S., N. Aprinita, Hendarti. 1990. Research shrimp waste as an industrial material chitin and chitosan. Indonesian Research and Development Center of Agricultural Industrial Crops. Bogor. 
[35] Herdyastuti, N., T.J. Raharjo, Mudasir, S. Matsjeh. 2009. Chitinase and chitinolytic microorganism: isolation, charactirization and potential. Indones. J. Chem. 9(1). 3747.

[36] Pratiwi, R.S., T.E. Susanto, Y.A.K. Wardani, A. Sutrisno. 2014. Kajian pustaka: enzim kitinase dan aplikasi dibidang industri. Jurnal Pangan dan Agroindustri. 3. 878887.

[37] Purkan, B., A. Azizah, Baktir, S. Sumarsih. 2014. Eksplorasi bakteri kitinolitik dari sampah organik : Isolasi dan karakterisasi enzim kitinase. Jurnal Molekul. 9(2). 128135.

[38] Rachmawaty, Madihah. 2013. Potensi perlakuan awal limbah kulit udang untuk produksi enzim kitinase oleh Trichoderma virens pada fermentasi substrat padat. Jurnal Bionature. 14(1). 33-37.

[39] Sandhya, C., L.K. Adapa, K.M. Nampoothiri, P. Binod, G. Szakacs, A. Pandey. 2003. Extracellular chitinase production by Trichoderma harzianum in submerged fermentation. J. Basic Microbiol. 44(1). 4958.

[40] Nampoothiri, K.M., T.V. Baiju, C. Sandhya, A. Sabu, G. Szakacs, A. Pandey. 2003. Process optimization for antifungal chitinase production by Trichoderma harzianum. Process Biochem. 39. 15831590.

[41] Bohlmann, J.A., D.O. Schisler, K. Hwang, J.P. Henning, J.R. Trinkle, T.B. Anderson, J. Donald, A. Vanderhoff. 2004. N-Acetyl-DGlucosamine and process for producing NAcetyl-D-Glucosamine. United States Patent US 6,693,188 B2.

[42] Sitanggang, A.B., H.S. Wu, S.S. Wang, Y.C. Ho. 2010. Effect of pellet size and stimulating factor on the glucosamine production using Aspergillus sp. BCRC 31742. Biores. Technol. 101(10). 35953601.

[43] Wulandari, F. 2009. Optimization of production of $\mathrm{N}$-acetylglucosamine from chitin through fermentation by Aspergillus rugulosus 501. Master Thesis. Department of Biochemistry. Bogor Agricultural University. Bogor. 